\title{
Electric heating units in pollination bags avoid damage to flowers by spring frost
}

\author{
J. CH. FERRAND \\ INRA, Station d'Amélioration des Arbres forestiers \\ Centre de Recherches d'Orléans \\ Ardon, F 45160 Olivet
}

\begin{abstract}
Summary
An effective, cheap and simple heating device was designed by INRA (Orléans) to prevent flower frost damages in outdoor controlled crosses. It consists of a small electrical resistance which is inserted in each individual pollination bag. A field experiment conducted on larch trees showed that not only the number of living flowers is significantly increased after a frost period but also the number of full seeds per cone.
\end{abstract}

Key words : Control pollination, frost protection, electric heating, Larix.

Controlled crosses are essential for forest tree breeding, but spring frost can destroy the pollinated female strobili. For example, at the INRA Forest Tree Breeding Station in Orléans (France), frost in March and April frequently damages flowers of larch, Douglas fir, walnut and wild cherry. It has been suggested that controlled crosses be done on grafted stocks in heated greenhouses. An effective and much less expensive method has been developed, that increases seed yield from controlled crosses. It consists of a small heating device placed inside the pollination bag in the field.

The device is constructed of $0.16 \mathrm{~mm}$ diameter enamel coated constantine wire sandwiched between strong adhesive tape and aluminium foil. The aluminium foil increases the heat radiation surface and avoids excessive temperature. Experiments in a controlled temperature chamber showed that in still air a unit with dimensions of $25 \times 10 \mathrm{~cm}$ could increase the temperature in a $50 \times 15 \times 12 \mathrm{~cm}$ paper pollination bag by $1^{\circ} \mathrm{C}$ per watt.

In 1983, a field trial of the heating units was performed in the clone banks of hybrid larch (Larix $x$ eurolepis Henry) and of European larch (Larix decidua Mill.) at Orléans. Household current (220VAC) was brought to the clone bank and transformed to 24VAC. The transformed current was then distributed in the orchard by ordinary insulated wire terminated with inexpensive domestic female connectors. The heating units had a $2.5 \mathrm{~m}$ cord and a special male/female plug which allowed connecting several units together (fig. 1). Heating was manually switched on every night, and during days with temperatures below freezing. 


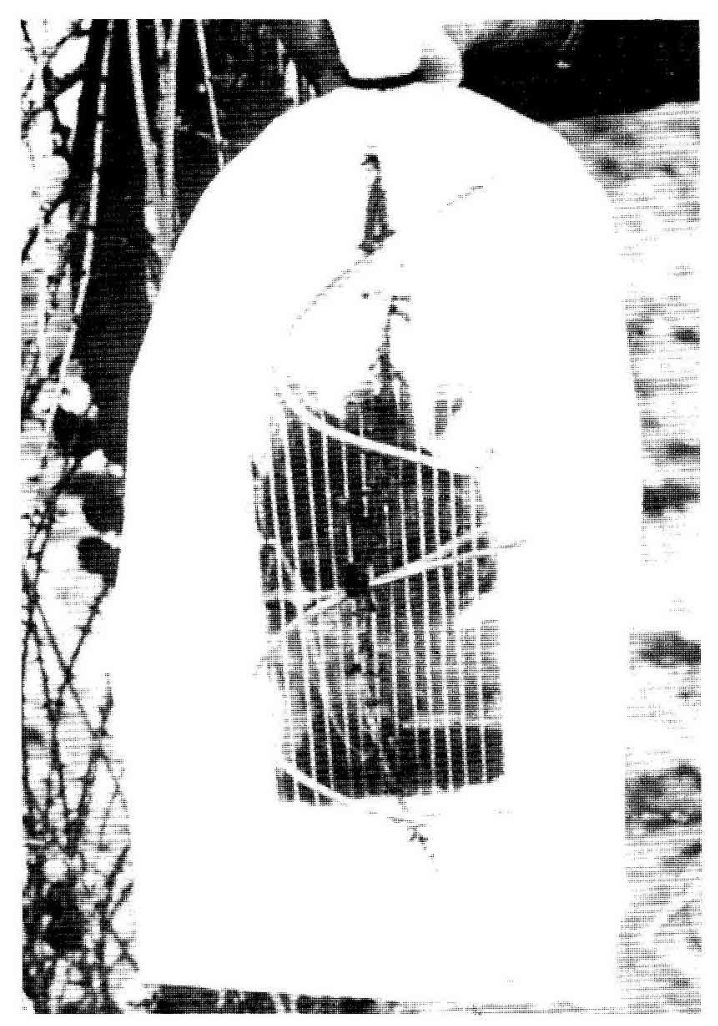

FIG. 1

The heating device developed by INRA (Orléans) to prevent strobili frost damage. Résistance mise au point par TINRA ả Oriéans pour èviter les dègàts de gelée aux strobiles.

Two experiments were conducted, each with three treatments : no heating unit in the pollination bag, $6 \mathrm{~W}$ heating unit, and $12 \mathrm{~W}$ heating unit. In experiment $\mathrm{A}$, each treatment was replicated 10 times on 8 different European larch clones and a single pollen source was used. In experiment $B$, each treatment was replicated 30 times on 14 different hybrid larches and 9 different pollen sources were used. Flowers were pollinated four times, about every second day.

Female strobili were counted before pollination and after the bags were removed about two months later. During the " heating period» of March and April, minimum air temperatures dropped below freezing 10 times, but inside the bags heated by $12 \mathrm{~W}$ units the temperature never fell below freezing. In September cones were harvested, seeds were extracted manually and full seeds were separated by ethanol flotation. The data were submitted to an analysis of variance (table 1 ).

Heating significantly (at 5 p. 100 level) increased the percentage of non damaged female strobili. In experiment $A$, the percentage of remaining flowers was 47 p. 100 for control (unheated), 66 p. 100 for $6 \mathrm{~W}$ heating and 87 p. 100 for $12 \mathrm{~W}$; and in experi- 
TABLE 1

Effect of heating on strobili survival and seed production of European larch and hybrid larch. Effet du chauffage sur la survie des strobiles et la production de graines des melèzes d'Europe et hybrides.

\begin{tabular}{|c|c|c|c|c|}
\hline \multirow{2}{*}{ Heating unit } & \multirow{2}{*}{ No of bags } & \multirow{2}{*}{$\begin{array}{l}\text { Strobili producing } \\
\text { cones (p. 100) }\end{array}$} & \multicolumn{2}{|c|}{ Full seeds } \\
\hline & & & per cone & per flower \\
\hline A. European Larch & & & & \\
\hline None . . . . . . . . . & 10 & $47 b^{(2)}$ & $13 \mathrm{~b}$ & $7.6 \mathrm{~b}$ \\
\hline $6 \mathrm{~W} \ldots \ldots \ldots$ & 10 & $66 \mathrm{ba}$ & $24 \mathrm{ba}$ & $14 \mathrm{ba}$ \\
\hline $12 W \ldots \ldots \ldots$ & 9 & $87 \mathrm{a}$ & $27 \mathrm{a}$ & 22 a \\
\hline B. Hybrid Larch & & & & \\
\hline None . . . . . . . . . & 26 & $72 \mathrm{~b}$ & $14 a$ & 9 \\
\hline $6 W \ldots \ldots \ldots$ & 29 & 98 a & $19 a$ & 17 a \\
\hline $12 \mathrm{~W}$ & 27 & $85 \mathrm{a}$ & $18 \mathrm{a}$ & $14 a b$ \\
\hline
\end{tabular}

(1) Analysis of variance conducted on aresin transformation of data.

(2) Numbers in a column followed by the same letter are not statistically different at the $5 \%$ level.

ment B the values were respectively 72 p. 100,98 p. 100 and 95 p. 100 . In experiment A only, the number of full seeds per harvested cone also increased with heating : 13 seeds (control), 24 seeds $(6 \mathrm{~W})$ and 27 seeds (12W). As a result, the number of full seeds divided by the number of strobili initially present ranged in experiment $A$ from 7.6 for control to 22 for $12 \mathrm{~W}$ heating. In experiment $\mathrm{B}$, it ranged from 9 to 17 for control and $6 \mathrm{~W}$ heating respectively. The lower number of seeds for $12 \mathrm{~W}$ than for $6 \mathrm{~W}$ unit might be due to excessive heating, especially because our hybrids were flowering one week later than European larch. In any case, except for the number of full seeds per cone of hybrid larch, one of the two heating options always provided significantly better results than the check (no heating) option.

These results showed that, compared to the same number of « ordinary » bags, electrically heated pollination bags could result in a doubled or tripled seed harvest. On the other hand, grafted stocks crossed in a heated greenhouse usually give around 5 full seeds per cone. Therefore, a larch clone bank of one hectare has now been fully equiped for heating every pollination bag. $10 \mathrm{~W}$ heating units are used and an electronic regulation has been added. The total cost, including a $400 \mathrm{~m}(220 \mathrm{~W})$ cable dug into the ground at $1,50 \mathrm{~m}$ depth, was $1 / 10$ the cost of a greenhouse allowing the same number of crosses to be performed.

Spring frosts were very severe too in March 1985, with 20 days below freezing, and destroyed a large part of larch flowers in the open field. But after removing the heated bags, $70 \mathrm{p}$. 100 of the artificially pollinated flowers were still living.

In conclusion, electric heating of pollination bags is a quick, cheap and efficient way to increase success in controlled crossing of spring frost sensitive tree species.

Reçu le 4 novembre 1987. 


\section{Résumé \\ Des unités de chauffage électrique placées dans les sacs à pollinisation empêchent les dégâts de gelée de printemps.}

De manière à éviter les dégâts de gelée lors des croisements contrôlés en champ, l'INRA d'Orléans a mis au point un système de chauffage individuel des sacs de pollinisation. Il s'agit d'une résistance électrique que l'on glisse dans les sacs. Une expérience conduite dans un parc à clones de mélèzes a montré l'efficacité du système ; il permet à un coût très réduit, d'augmenter significativement non seulement le nombre de fleurs vivantes après une période de gel sévère, mais aussi le nombre de graines pleines par cone.

Mots clés : Pollinisation contrôlée, dégât de gelée, chauffage, Larix. 